\title{
Can CabECO® technology be used for the disinfection of highly fecal-polluted surface water?
}

J. Isidro ${ }^{1}$, J. Llanos ${ }^{1}$, C. Sáez ${ }^{1, *}$, D. Brackemeyer ${ }^{2}$, P. Cañizares ${ }^{1}$, T. Matthee ${ }^{2}$, M. A. Rodrigo $^{1}$

${ }^{1}$ Chemical Engineering Department, Faculty of Chemical Sciences and Technologies, University of Castilla-La Mancha, Edificio Enrique Costa Novella. Campus Universitario s/n, 13005 Ciudad Real, Spain

${ }^{2}$ CONDIAS GmbH, Fraunhoferstraße 1b, 25524 Itzehoe- Germany

\begin{abstract}
In this work, the disinfection of highly fecal-polluted surface water is studied using a new electrochemical cell especially designed to produce ozone in water with very low conductivity (CabECO ${ }^{\circledR}$ cell manufactured by CONDIAS). The disinfection tests were carried out in discontinuous mode in order to evaluate the influence of the electrode current charge passed. The effect of current density is also studied in order to optimize disinfection conditions and simultaneously prevent the formation of undesirable byproducts (chlorates and perchlorates) during the electrolysis. Results demonstrate that this technology is robust and efficient and it can attain suitable disinfection of water. During electrolysis, chloride contained in the water is oxidized to hypochlorite and this compound is combined with ammonia to form chloramines. Both hypochlorite and chloramines (formed by the well-known break point reaction) promote persistent disinfection and they seem to be the main responsible for the disinfection attained during the electrochemical process. Chlorate and perchlorate can also be produced, although the low concentrations of chloride in the water tested make them not relevant. Removal of TOC under the operations conditions applied is not very efficient (although it reaches
\end{abstract}


$50 \%$ in two hours) and the production of trihalomethanes (THM) is very low and always below $100 \mathrm{ppb}$.

\section{Keywords}

Electrolysis; disinfection; CabECO®; perchlorate; chloramines; diamond anodes

\section{Highlights}

- CabECO ${ }^{\circledR}$ cell can be used for direct disinfection of fecal-polluted water

- The higher the electric charge passed per liter, the higher is the removal of pathogens attained

- Electrolysis at suitable intensities for disinfection is not very efficient for the removal of TOC

- Despite the cell produces ozone, hypochlorite and chloramines may explain the disinfection of water

- Chlorates and perchlorates formation depends on current density

*Author to whom all correspondence should be addressed: cristina.saez@uclm.es 


\section{Introduction}

The loss of quality of water sources associated to pollution caused by human activities related to the development of the modern Society (such as industries, farms, ...) and the climate change (which is changing abruptly the rain patterns, producing more extreme drought periods in many regions) are contributing to the water scarcity in developing areas and poor countries. Thus, the search for high-quality reservoirs of water and/or the development of technologies that can improve the quality of water is a topic of the major interest.

Nowadays, surface water and groundwater are the two major sources of drinking water, and, in various countries, reclaimed water has also become a new source of drinking water. However, in many others countries this source is still very controversial and it is banned by regulations for the production of drinking water, although it is allowed for many other applications, such as irrigation (Rodrigo et al., 2010).

Surface water (coming from lakes, artificial reservoirs, rivers and wetlands) naturally contains sediments and different organic species such as humic and fulvic acids, etc. The concentrations of each of these pollutants strongly depend on the level of eutrophication of the source and the hydrodynamic characteristics of the water catchment area. Because of that, its aspect is sometimes turbid. Additionally, in rural areas an additional problem may occur: the fecal pollution of the water sources caused by farms. In several countries this activity seems to be seriously affecting the quality of fresh water reservoirs used for human supply, making necessary the oversizing of the typical technologies used to obtain the drinking water or even to design new types of treatment technologies capable to face the occurrence of this particular pollution. 
Generally, the treatment of surface water is oriented to remove turbidity (with all pollutant associated) and kill microorganisms and it typically consists of the sequence: coagulationflocculation- sedimentation- filtering- adsorption- chemical disinfection. Chemical disinfection technologies, such as chlorination or ozonation, present different drawbacks that limit their application. Among them, formation of disinfection by-products and the loss of disinfection efficiency through the presence of organic matter are crucial when considering those technologies (Arapoglou et al., 2003). The applicability of physical disinfection processes such as UV irradiation, membrane separation and thermal disinfection is associated with high cost and maintenance efforts and does not fulfil the requirements for primary and residual water disinfection. In this point, disinfection using electrochemical technology appears as an environmentally friendly, economically and operationally competitive technology to be applicable against a wide range of microbiological contaminations in water (Kolosov et al., 2001; Oturan et al., 2001; Louhichi et al., 2008; Ma et al., 2010; Piuleac et al., 2012). The direct electrolysis of the water to be disinfected without the further addition of chemicals is based on the production of oxidants from the oxidation of anions directly contained in the raw water or wastewater, such as chloride, sulfate, phosphate or carbonate (Canizares et al., 2009). These powerful oxidants can attack microorganisms and help to remove them from solution. A critical factor in these electrochemical processes is the role of the anode material(Labiadh et al., 2016). Among others, boron doped diamond (BDD) has shown remarkable properties to be applied as anodic material (Pulgarin and Kiwi, 1996; Vlyssides et al., 2004; Ribeiro et al., 2005; Yuan et al., 2006; Skoumal et al., 2008). In addition to the anodic production of oxidants from anions contained in the water(Velazquez-Pena et al., 2013), the cathodic production of hydrogen peroxide by reduction of the oxygen produced anodically (which typically saturates water during electrolysis)(Valero et al., 2017) and the formation of other oxidants such as 
ozone (Heim et al., 2015; Rajab et al., 2015) must take into account as they can contribute to the disinfection action of the system. Unfortunately, electrochemical disinfection using BDD electrodes can lead to the formation of undesirable disinfection by-products such as the highly oxidized chloro-species chlorate and perchlorate (Bergmann et al., 2009; Schaefer et al., 2015) which have a possible carcinogenic effect on human health. Moreover, the reaction of halogen species with organic molecules found in water will promote the formation of the harmful adsorbable organically bound halogens (AOX) and the trihalomethanes (THMs). There are many electrochemical technologies and one of the most promising in order to avoid this type of problems is the CabECO ${ }^{\circledR}$ process (manufactured by CONDIAS)(Fryda and Matthee; Fryda et al., 2016). It consist of a special cell design made with diamond anodes and optimized to produce ozone in low conductivity water. Because of this special features this technology has been proven to be efficient in the indirect disinfection by dosing ozone to water.

This work tries to establish if the $\mathrm{CabECO}{ }^{\circledR}$ technology equipped with diamond electrodes is efficient in the direct disinfection of surface water with fecal pollution. The disinfection of the surface water model tested in this work was evaluated by the quantification of two indicators of pathogenicity: Total Coliforms and Pseudomonas Aeruginosa. In addition, Total Aerobic Microorganism were also monitored in order to check the effect of the technology not only in disinfection but also in sterilization. The effect of the current density and operation mode in both disinfection efficiency and formation of undesirable by products were also evaluated.

\section{Materials and methods.}

\subsection{Chemicals and raw water}

To simulate the surface water with fecal pollution, the water collected at the inlet of the municipal Water Treatment Plant (WTP) of Ciudad Real (which received directly by 
pumping, surface water obtained directly from the Gasset Reservoir) was merged with the effluent of the secondary clarifier of the municipal Wastewater Treatment Plant (WWTP). The volumetric ratio used for the mixture was 95/5 (volume surface water/volume secondarily treated wastewater). Table 1 shows the main characteristics of the water sample evaluated in this work, taken in July 2016, which was merged and disinfected in less than 120 minutes from the moment in which it was taken (to test the technology with fresh water).

Table 1. Main characteristic of the model surface water used.

\begin{tabular}{|l|c|c|c|c|c|}
\hline Parameter & Value & Units & Parameter & Value & Units \\
\hline Total coliforms & 4,935 & CFU $100 \mathrm{~mL}^{-1}$ & $\mathrm{Cl}^{-}$ & 59.8 & $\mathrm{mg} \mathrm{Cl} \mathrm{L}^{-1}$ \\
\hline E. Coli & 1,524 & CFU $100 \mathrm{~mL}^{-1}$ & $\mathrm{SO}_{4}^{2-}$ & 13.0 & $\mathrm{mg} \mathrm{S} \mathrm{L}^{-1}$ \\
\hline P. Aeruginosa & 45 & CFU $100 \mathrm{~mL}^{-1}$ & $\mathrm{~F}^{-}$ & 0.06 & $\mathrm{mg} \mathrm{L}^{-1}$ \\
\hline $\mathrm{pH}$ & 8.12 & Units & $\mathrm{Br}$ & 0.45 & $\mathrm{mg} \mathrm{L}^{-1}$ \\
\hline Conductivity & 374 & $\mu \mathrm{Sc}^{-1}$ & $\mathrm{Na}^{+}$ & 34.3 & $\mathrm{mg} \mathrm{L}^{-1}$ \\
\hline TOC & 6.4 & $\mathrm{mg} \mathrm{C} \mathrm{L}$ & $\mathrm{K}^{+}$ & 5.1 & $\mathrm{mg} \mathrm{L}^{-1}$ \\
\hline $\mathrm{NH}_{4}^{+}$ & 0.53 & $\mathrm{mg} \mathrm{N} \mathrm{L}$ & $\mathrm{Ca}^{-1}$ & 52.6 & $\mathrm{mg} \mathrm{L}^{-1}$ \\
\hline $\mathrm{NO}_{3}{ }^{-}$ & 0.50 & $\mathrm{mg} \mathrm{N} \mathrm{L}^{-1}$ & $\mathrm{Mg}^{2+}$ & 19.6 & $\mathrm{mg} \mathrm{L}^{-1}$ \\
\hline
\end{tabular}

\subsection{Analytical techniques.}

A complete physico-chemical characterization was carried out. Concentration of ions was measured by ion chromatography using a Metrohm 930 Compact IC Flex coupled to a conductivity detector. A Metrosep A Supp 7 column was used to determine anions, by passing through it a mobile phase consisted of $85: 15 \mathrm{v} / \mathrm{v} 3.6 \mathrm{mM} \mathrm{Na} 2 \mathrm{CO}_{3} /$ acetone with a flow rate of $0.8 \mathrm{~cm}^{3} \mathrm{~min}^{-1}$. In addition, a Metrosep A Supp 4 column was used to analyze cations, by passing through it a mobile phase consisted of $1.7 \mathrm{mM} \mathrm{HNO}_{3}$ and $1.7 \mathrm{mM}$ 2,6-pyridinedicarboxylic acid with a flow rate of $0.9 \mathrm{~cm}^{3} \mathrm{~min}^{-1}$. The temperature of the oven was 45 and $30^{\circ} \mathrm{C}$ for the determination of anions and cations, respectively. The volume injection was $20 \mu \mathrm{L}$. TOC concentration was monitored using a Multi N/C 3100 
Analytik Jena analyzer. Hypochlorite was analyzed by titration with $0.001 \mathrm{M} \mathrm{As}_{2} \mathrm{O}_{3}$ in 2 M NaOH (Wilpert, 1957; Freytag, 1959)(Wilpert, 1957; Freytag, 1959)(Wilpert, 1957; Freytag, 1959)(Wilpert, 1957; Freytag, 1959). Oxidants were determined iodometrically (Canizares et al., 2009). Inorganic chloramines were determined following the DPD standard method described in literature (APHA-AWWA-WPCF, 1998). The $\mathrm{pH}$ and conductivity were measured using a CRISON pH25+ and CRISON CM35+, respectively. The organochorinated intermediates were analyzed by GC-MS using a Thermo Scientific DSQ II Series Single Quadrupole GC-MS with a NIST05-MS library. The column was a polar TR-WAXMS (30 $\mathrm{m} \times 0.25 \mathrm{~mm} \times 0.25 \mu \mathrm{m})$. The temperature ramp was $70^{\circ} \mathrm{C}$ for 1 $\min , 30^{\circ} \mathrm{C} \min ^{-1}$ up to $300{ }^{\circ} \mathrm{C}$ and hold time 5 minutes. The inlet, source and transfer line temperatures were 250,200 and $300^{\circ} \mathrm{C}$, respectively.

Regarding microbiological characterization, microbiological tests conform to standard methods were used: UNE-EN ISO 6222:1999 and UNE-EN 12780:2003 for the quantification of Total Aerobic Microorganisms at $22^{\circ} \mathrm{C}$, Escherichia Coli and Pseudomonas Aeruginosa, respectively.

\subsection{Electrochemical cell.}

Electrolyses were carried out in a CabECO® cell, delivered by CONDIAS (Germany). It is a zero-gap cell equipped with diamond electrodes (total active area of $24 \mathrm{~cm}^{2}$ ). A scheme of the cell is presented in Figure 1-a. It was connected to the water reservoir by a centrifugal pump and powered by a Promax DC FA-376 power supply. A Keithley 2000 multimeter was used to monitor current and cell voltage. Outlet of the cell was recirculated to the water reservoir in the discontinuous tests and to another tank in the continuous tests. A picture of the setup used is shown in Figure 1. 


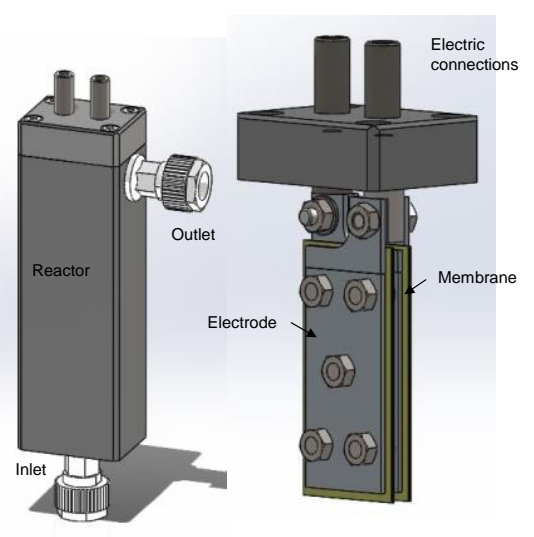

a)

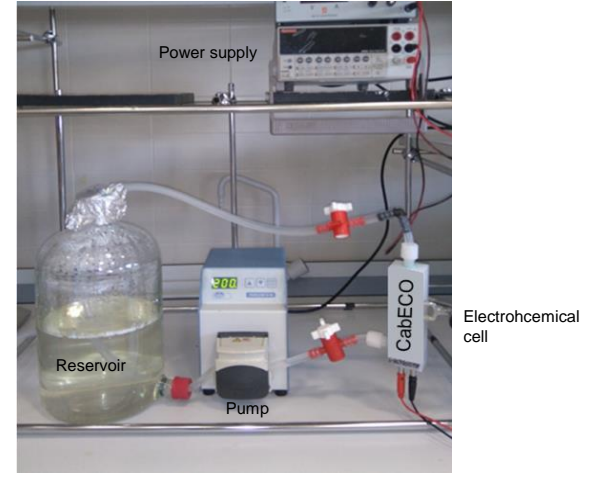

b)

Figure 1. a) $\mathrm{CabECO}{ }^{\circledR}$ cell, b) Experimental setup

\subsection{Experimental procedure.}

All the tests were carried out under galvanostatic mode and in discontinuous operation mode by recirculating the water between a reservoir tank and the $\mathrm{CabECO}{ }^{\circledR}$ cell. The current density applied was within the range 0.83 - $833 \mathrm{~A} \mathrm{~m}^{-2}$ (3 log-units). In all cases, a heat exchanger with a thermostatized bath (Digiterm 100, JP Selecta, Barcelona, Spain) was used to maintain the temperature at the desired set point $\left(25^{\circ} \mathrm{C}\right)$. Table 2 summarizes the main operation conditions applied. The measurement of pathogens and disinfectant species (free and combined chlorine compounds) were carried out immediately after taking the samples, and thus it was not necessary the addition of chemical reagents to stop the reaction between microorganisms and disinfectants.

Table 2. Operation conditions applied during the evaluation of CabECO $®$ for disinfection.

\begin{tabular}{|l|c|c|c|c|}
\hline Test no. & $\mathbf{1}$ & $\mathbf{2}$ & $\mathbf{3}$ & $\mathbf{4}$ \\
\hline Current density $\left(\mathbf{A ~ m}^{-\mathbf{2}}\right)$ & 0.0 & 8.33 & 83.33 & 833.33 \\
\hline Duration of the test $(\mathbf{m i n})$ & 120 & 120 & 120 & 120 \\
\hline Average cell voltage $(\mathbf{V})$ & 0.0 & 3.2 & 5.4 & 10.0 \\
\hline Recirculation flowrate $\left(\mathbf{L ~ h}^{-\mathbf{1}}\right)$ & 50.0 & 50.0 & 50.0 & 50.0 \\
\hline Volume of water treated $(\mathbf{L})$ & 5.0 & 5.0 & 5.0 & 5.0 \\
\hline
\end{tabular}




\begin{tabular}{|l|l|l|l|l|}
\hline Maximum specific charge passed $\left(\mathbf{A h ~ L}^{-1}\right)$ & 0.000 & 0.008 & 0.080 & 0.800 \\
\hline
\end{tabular}

\section{Results and discussion}

The disinfection of the surface water model tested in this work was evaluated by the quantification of two pathogens indicators: Total Coliforms and Pseudomonas Aeruginosa. In addition, the Total Aerobic Microorganism was also monitored because this parameter may give important information about the sterilization capability of this technology (if any). Figure 2 shows the changes in the concentration of these parameters during the electrolysis of the model surface water in discontinuous mode at the three different current densities studied. For the sake of comparison, a reference test was also carried out and results are also included in the Figure. In this reference test, water was passed through the cell at the same flowrate but no current was applied. Results are plotted in semi-log scale for a better comparison.
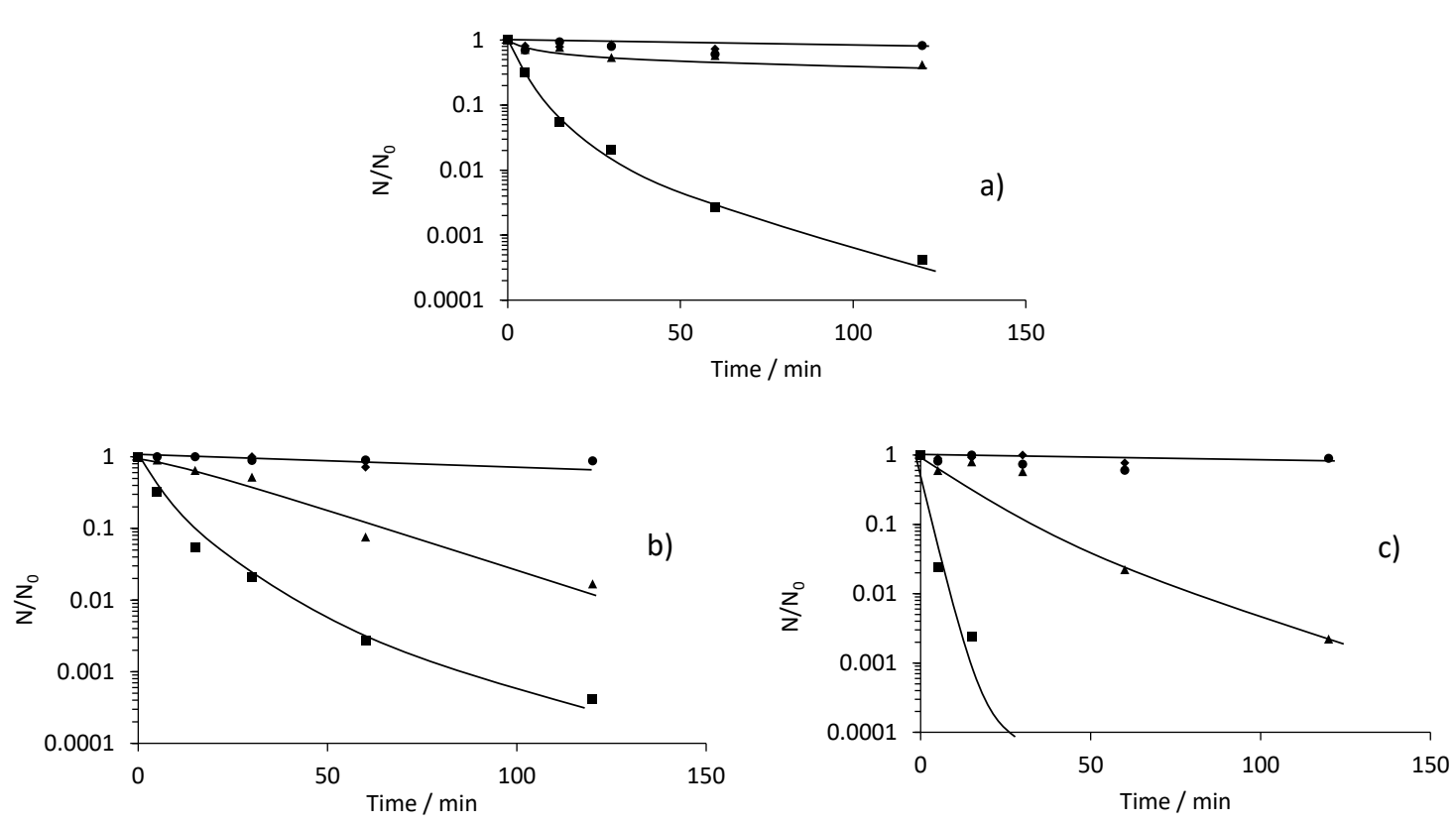
Figure 2. Changes in the concentration of total aerobic microorganism (a), total coliforms (b) and pseudomonas aeruginosa (c) during the electrolysis carried out in discontinuous mode at $0.00 \mathrm{~A} \mathrm{~m}^{-2} ; \diamond 8.3 \mathrm{~A} \mathrm{~m}^{-2} ; \boldsymbol{\Delta} 83.3 \mathrm{~A} \mathrm{~m}^{-2} ; \boldsymbol{\square} 833.3 \mathrm{~A} \mathrm{~m}^{-2}$.

As expected, no changes in the concentration of microorganisms are observed in the reference test. Likewise, disinfection efficiency in the case of using low values of current density $\left(8.3 \mathrm{~A} \mathrm{~m}^{-2}\right)$ is negligible, because the changes observed in the three biological indicators are almost nil during the whole tests. This is not the case for the other two tests carried out at higher current densities. Thus, the disinfection efficiency of the electrochemical technology depends strongly on the applied current density, that is, the higher the current density, the higher is the disinfection rate and the lower is the number of microorganisms that remains in the water after the treatment. Then, high values of current density (above $83.3 \mathrm{~A} \mathrm{~m}^{-2}$ ) are required to attain disinfection. Likewise, the treatment time is also an important parameter and the longer this time, the higher is the removal of microorganisms. This treatment time (h) is related to the applied electrical charge (Ah) by equation (1).

$$
q(A h)=I(A) \cdot t(h)
$$

Experimental data of the electrolysis fit well to first order kinetic (linear trend in semilog plot), except for the tests carried out at the highest current density (in which more complex processes maybe occurring). Figure 3 compares the kinetic constants calculated for the removal of the three biological indicators tested during batch-electrolysis. As can be observed, kinetic constants significantly depend on the current density for each biological indicator. The disinfection rate increases almost proportionally with the current density, that is, changing by one log-unit the current density produces a one-fold increase in the removal rate. In comparing the decrease in the three parameters, it can be stated that Total Coliforms and Pseudomonas Aeruginosa are removed around 2 times faster 
than the Total Aerobic Microorganisms, meaning that the electrochemical technology is more efficient for disinfection (removal of pathogens) than for sterilization (removal of microorganism, pathogens or not).

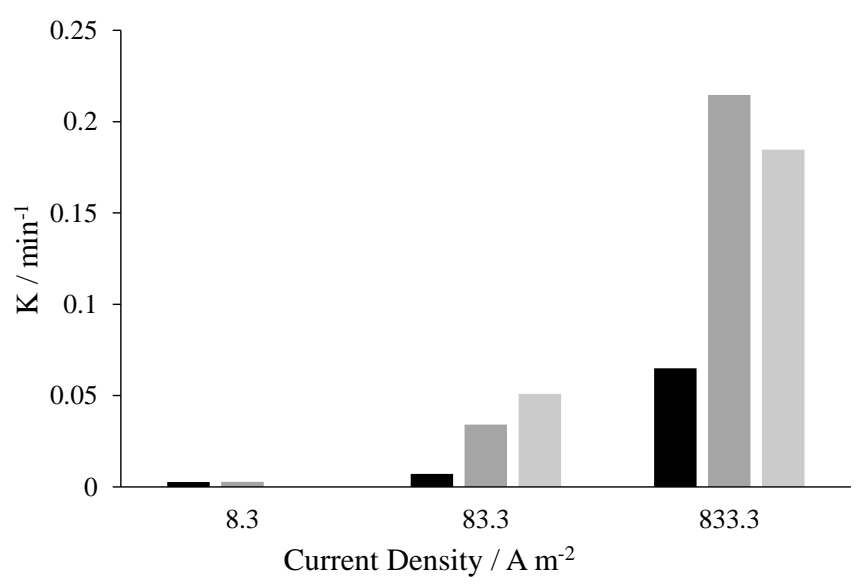

Figure 3. Kinetic constants calculated for the pathogens presented in model surface water as function of the current density applied during batch-electrolysis. (ם) Total microorganisms, ( $\square$ ) Total coliforms, ( ) Pseudomonas aeruginosa.

Figure 4 shows the changes in TOC in the four experiments shown previously. As can be observed, TOC decreases with the application of electrical current charge during the tests but this removal does not depend on the applied current densities and after two hour of electrolysis it is far away from the complete mineralization of the organic load obtained (it attains 50\% removal). This suggests that within the range of current densities applied, the process is not very efficient for TOC removal and it cannot be proposed for the simultaneous disinfection and removal of persistent organic pollutants, because the electrical charges required would be not cost-effective. It has to be taken into account that the organic load of the water treated comes mostly from the TOC added with the secondarily treated wastewater and typically it consists of pollutants which were refractory to the biological treatment. The nil effect of the current density on the depletion of TOC suggests that the oxidation of this species can be carried out by ozone produced 
in the cell. This type of cells are known to produced huge amounts of ozone by the reaction of hydroxyl radical with oxygen (eq. 2) even for low current densities, regardless of the salinity of the water electrolysed. Thus, with the lowest current density, the amount produced seems to be enough to produce the oxidation, not finding improvement with the production of higher amounts of ozone.

$$
\mathrm{O}_{2}+2(\mathrm{OH}) \bullet \mathrm{O}_{3}+\mathrm{H}_{2} \mathrm{O}
$$

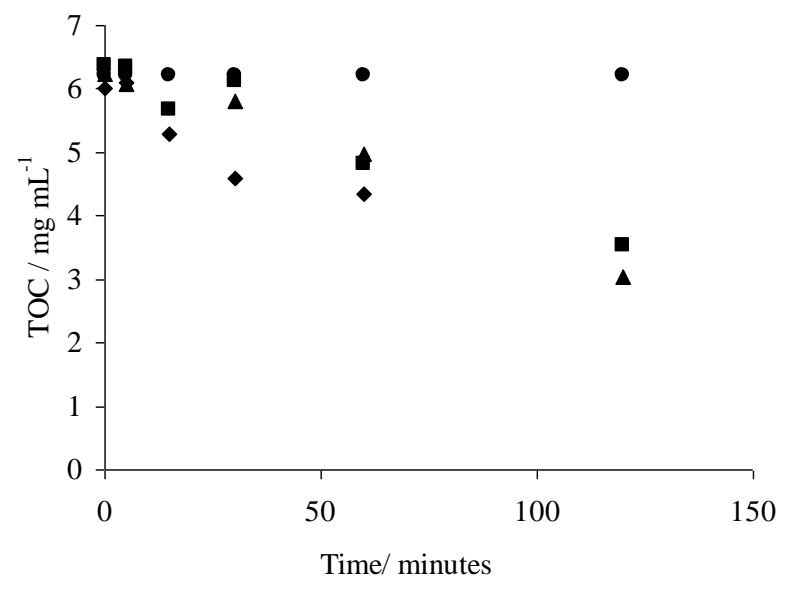

Figure 4. Changes in the TOC concentration during the electrolysis carried out in discontinuous mode at $0.00 \mathrm{~A} \mathrm{~m}^{-2} ; \bullet 8.3 \mathrm{~A} \mathrm{~m}^{-2} ; \boldsymbol{\Delta} 83.3 \mathrm{~A} \mathrm{~m}^{-2} ; \boldsymbol{\square} 833.3 \mathrm{~A} \mathrm{~m}^{-2}$.

In this way, it has to be taken into account that salt content of water tested in this work is very low (only the salts contained in the raw mixture) and hence the formation of large amount of other powerful oxidants is not expected to be promoted. According to the ionic content of the raw water (see Table 1), chloride is the main anionic species with concentration around $60 \mathrm{mg} \mathrm{dm}^{-3}$ (quite low as compared to the concentration shown in literature for removal of organics in wastewater which are typically within the range 1000-3000 $\mathrm{mg} \mathrm{dm}^{-3}$ ). However, even at low concentration, it is expected the formation of chlorinated disinfectants that allows to explain the electrochemical disinfection and removal of organics because they are very reactive and can attack organics present in the 
solution. Figure 5 confirms this point and shows a decrease in the concentration of chlorides which increases with the current density and the electrolysis time. Anyhow, the concentration of this anion does not undergo very relevant changes and this means that after the treatment, chloride remains to be the primary chlorinated species in the system.

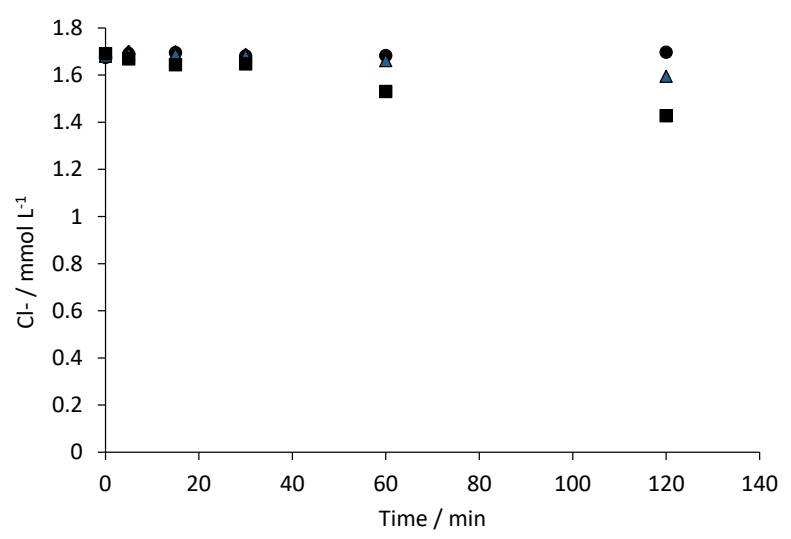

Figure 5. Changes in the concentration of chloride during the electrolysis carried out in discontinuous mode at $0.00 \mathrm{~A} \mathrm{~m}^{-2} ; \bullet 8.3 \mathrm{~A} \mathrm{~m}^{-2} ; \boldsymbol{\Delta} 83.3 \mathrm{~A} \mathrm{~m}^{-2} ; \mathbf{\square} 833.3 \mathrm{~A} \mathrm{~m}^{-2}$.

Chloride is expected to be oxidized to chlorine, which is further transformed into hypochlorite which, in turn, can undergo further oxidation or combination processes. Figures 6 and 7 show the distribution of these chlorinated species detected during the electrolysis in discontinuous mode, classified into desired (known as disinfectants) and non-desired species. For the sake of comparison, the same units $\left(\mathrm{mmol} \mathrm{Cl} \mathrm{L}^{-1}\right)$ has been used in these plots and insets with log scale have been added.

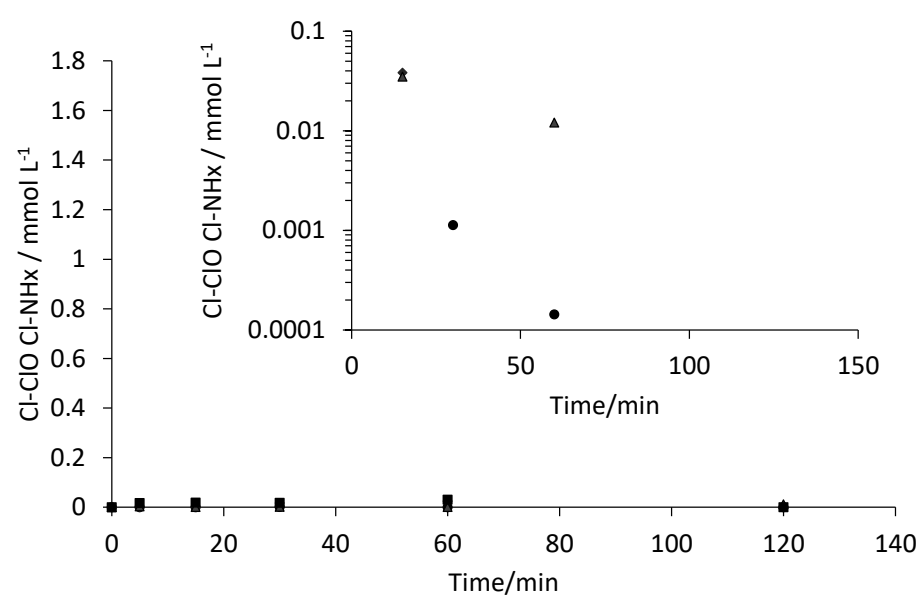


Figure 6. Changes in the concentration of disinfectants (chloramines + hypochlorite) during the electrolysis carried out in discontinuous mode at $\bullet 0.00 \mathrm{~A} \mathrm{~m}^{-2} ; \diamond 8.3 \mathrm{~A} \mathrm{~m}^{-2}$; $\Delta 83.3 \mathrm{~A} \mathrm{~m}^{-2} ; \mathbf{\square} 833.3 \mathrm{~A} \mathrm{~m}^{-2}$.

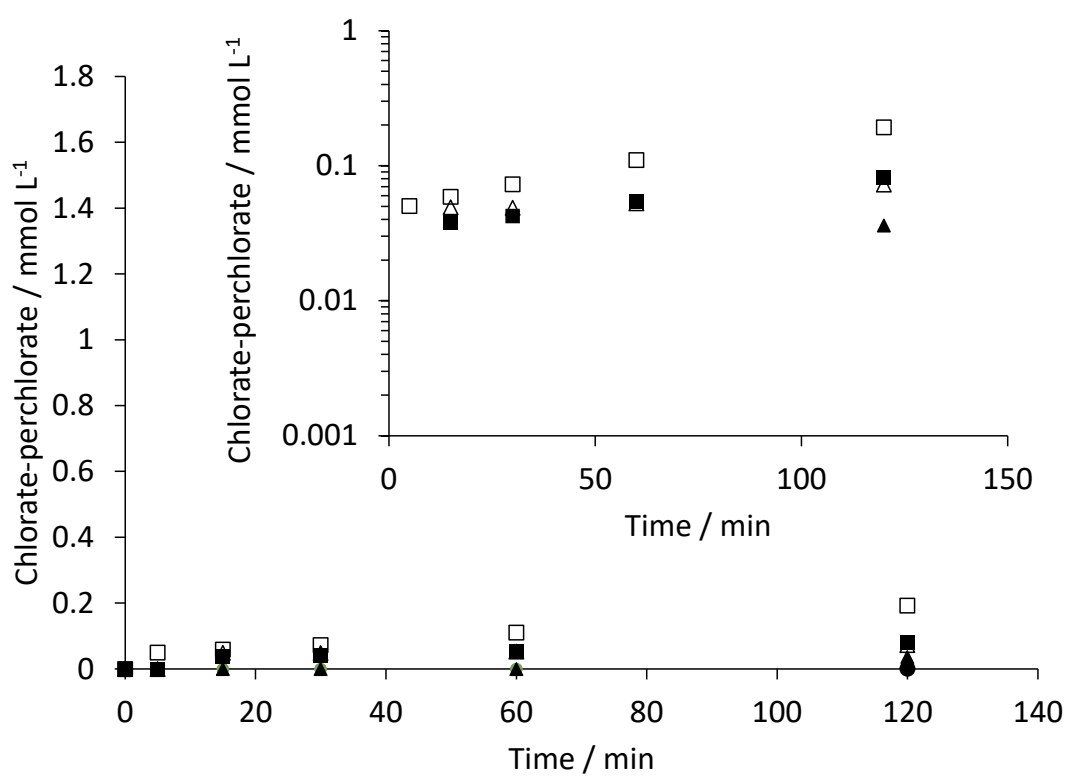

Figure 7. Changes in the concentration of hazardous chlorinated species (chlorate (empty) and perchlorate(full symbol)) during the electrolysis carried out in discontinuous mode at $0.00 \mathrm{~A} \mathrm{~m}^{-2} ; \diamond 8.3 \mathrm{~A} \mathrm{~m}^{-2} ; \boldsymbol{\Delta} 83.3 \mathrm{~A} \mathrm{~m}^{-2} ; \mathbf{\square} 833.3 \mathrm{~A} \mathrm{~m}^{-2}$.

As expected (Kolosov et al., 2001; Sanchez-Carretero et al., 2011), oxidation of chlorides leads to the formation of hypochlorite (eqs. 3 and 4), which behaves as an intermediate, being further oxidized to chlorite (eq. 5), chlorate (eq. 6) and perchlorate (eq. 7), either via direct oxidation or by mediated oxidation with hydroxyl radicals depending on the current density applied (Sanchez-Carretero et al., 2011)(Sanchez-Carretero et al., 2011)(Sanchez-Carretero et al., 2011)(Sanchez-Carretero et al., 2011). In fact, as can be observed, hypochlorite is not accumulated in the system and the primary oxidation products of the electrochemical processes are highly oxidized chlorates and perchlorates, in particular in the experiments carried out at largest current densities which were the most effective in the killing of microorganisms. These results agree with those published 
in literature in which it was pointed out the formation of these hazardous species (Cano et al., 2012; Cano et al., 2016). In fact, one of the main strategies proposed in literature to try to avoid the problem of the formation of perchlorate is the use of low current density (Cano et al., 2011) under which the massive formation of hydroxyl radicals is not favored and thus, the formation of highly oxidized chloro-oxospecies is minimized. This is a drawback of the technology, in which more research effort has to be done during the next years. However, in this case, as the concentration of chlorides in raw water is not important, the amount of hazardous species is not very high (under the legal limit) and it does not prevent the use of this treated water.

$$
\begin{aligned}
& 2 \mathrm{Cl}^{-} \rightarrow \mathrm{Cl}_{2}+2 \mathrm{e}^{-} \\
& \mathrm{Cl}_{2}+\mathrm{H}_{2} \mathrm{O} \rightarrow \mathrm{HClO}+\mathrm{Cl}^{-}+\mathrm{H}^{+} \\
& \mathrm{ClO}^{-}+\cdot \mathrm{OH} \rightarrow \mathrm{ClO}_{2}^{-}+\mathrm{H}^{+}+\mathrm{e}^{-} \\
& \mathrm{ClO}_{2}^{-}+\cdot \mathrm{OH} \rightarrow \mathrm{ClO}_{3}^{-}+\mathrm{H}^{+}+\mathrm{e}^{-} \\
& \mathrm{ClO}_{3}^{-}+\cdot \mathrm{OH} \rightarrow \mathrm{ClO}_{4}^{-}+\mathrm{H}^{+}+\mathrm{e}^{-}
\end{aligned}
$$

Furthermore, it is well known that hypochlorite is very active and it can react with other species present in the solution, and that this can affect to the formation of undesirable highly oxidized chlorine oxochlorinated species. Raw water tested contains ammonium ions which may chemically reacts with hypochlorite electrogenerated to produce chloramines by the well-known breakpoint chlorination (Eqs 8 to 11). Both hypochlorite and chloramines promote persistent disinfection and they seems to be the main responsible of the disinfection attained during the electrochemical process.

$$
\begin{gathered}
\mathrm{NH}_{3}+\mathrm{HClO} \leftrightarrow \mathrm{NH}_{2} \mathrm{Cl}+\mathrm{H}_{2} \mathrm{O} \\
\mathrm{NH}_{2} \mathrm{Cl}+\mathrm{HClO} \leftrightarrow \mathrm{NHCl}_{2}+\mathrm{H}_{2} \mathrm{O}
\end{gathered}
$$




$$
\begin{aligned}
& \mathrm{NHCl}_{2}+\mathrm{HClO} \leftrightarrow \mathrm{NCl}_{3}+\mathrm{H}_{2} \mathrm{O} \\
& \mathrm{NH}_{4}^{+}+3 \mathrm{HClO} \rightarrow \mathrm{N}_{2}+3 \mathrm{H}_{2} \mathrm{O}+5 \mathrm{H}^{+}+3 \mathrm{Cl}^{-}
\end{aligned}
$$

Besides inorganic intermediates, the formation of organics must be checked. Even more, taking into account that trihalomethanes (THM) are typically formed as by-product when chlorine is used to disinfect drinking water. THM are highly toxic and potentially carcinogenic, and thus their formation must be prevented. On base of this, the presence of short-chain organic acid and organochlorinated species was checked by HPLC and Mass-GC. Among them, only chloroform and dichlorobromomethane and bromoform were detected in trace concentration, and they were always in concentration below the limits set by the Spanish regulation (100 ppb).

Besides this, the concentrations of other relevant anions and cations presented in the raw water (see Table 1) were also monitored during the tests. Figure 8 shows the concentration of the different anions monitored in the two test carried out at the highest current densities.

No relevant changes were observed in the anions monitored, except in the case of bromide that slightly decreases during the tests due to the formation of higher oxidation state halospecies, as it has been just described for the case of chloride. As no bromate of perbromate anions were detected, the most plausible possibility is the formation of bromine, which can be stripped from the system explaining the experimental observation. Likewise, no brominated organics were detected by chromatography. Opposite to bromide and chloride, fluoride anions remain as refractory to the treatment. Regarding the other nonhalogenated species, the most important observation is that no changes in the sulfate concentration are produced during the disinfection. This may mean that within the conditions applied no peroxosulfate is formed in the treated water and hence this 
important oxidant does not behave as a disinfectant in this process, opposite to what it was observed in previous studies (Cotillas et al., 2016). In addition, the formation of nitrates during the tests is really surprising. As this species cannot be formed from the direct oxidation of ammonium ions (Lacasa et al., 2011), the most reasonable mechanisms to explain this increase is the oxidation of the organics contained in the water, which is known to produced nitrates from the organic nitrogen contained in the pollutants (Martin de Vidales et al., 2016).
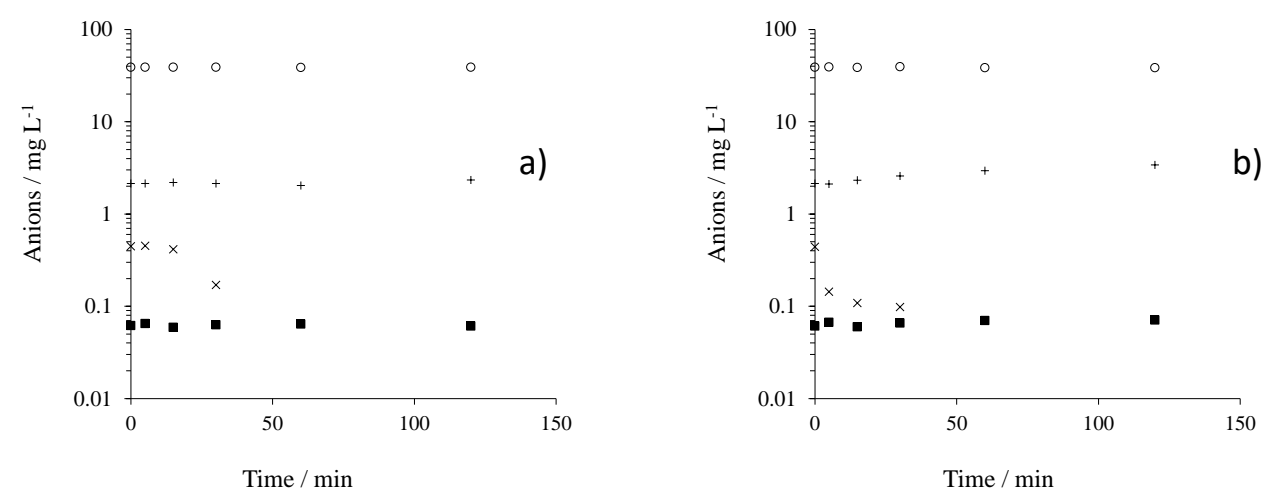

Figure 8. Changes in the concentration of anions during the electrolysis carried out in discontinuous mode at a) $83.3 \mathrm{~A} \mathrm{~m}^{-2}$ and b) $833.3 \mathrm{~A} \mathrm{~m}^{-2}$. Anions: $\mathbf{F}-; \mathrm{Br}^{-}$; + $\mathrm{NO}_{3}^{-}$; O $\mathrm{SO}_{4}^{2-}$

Regarding the concentration of cations (Figure 9), it was observed a decrease in the concentration of ammonium which may be associated with the production of chloramines and/or to the stripping of ammonia. Additionally, a slight decrease in the concentration of calcium ( $14.5 \%$ at 83.3 and $24.5 \%$ at $833.3 \mathrm{Am}^{-2}$, respectively) and magnesium (1.5 $\%$ at 8.3 and $18.5 \%$ at $833.3 \mathrm{~A} \mathrm{~m}^{-2}$, respectively) is observed, which may be associated to scaling in the cathode (formation of a layer of carbonates), although no relevant increase in the cell voltage was observed over the test. Anyway, this potential operation problem could be easily overcome by reversing periodically the polarity of the cell. It has to be taken into account that because of the special design of the CabECO® cell, the 
electrolyte circuit is not affected by the scale of the electrodes because the most active faces of the electrodes are directly in contact with the membrane and not with the water to be treated and the deposits can only be produced on the other surface of the electrodes.
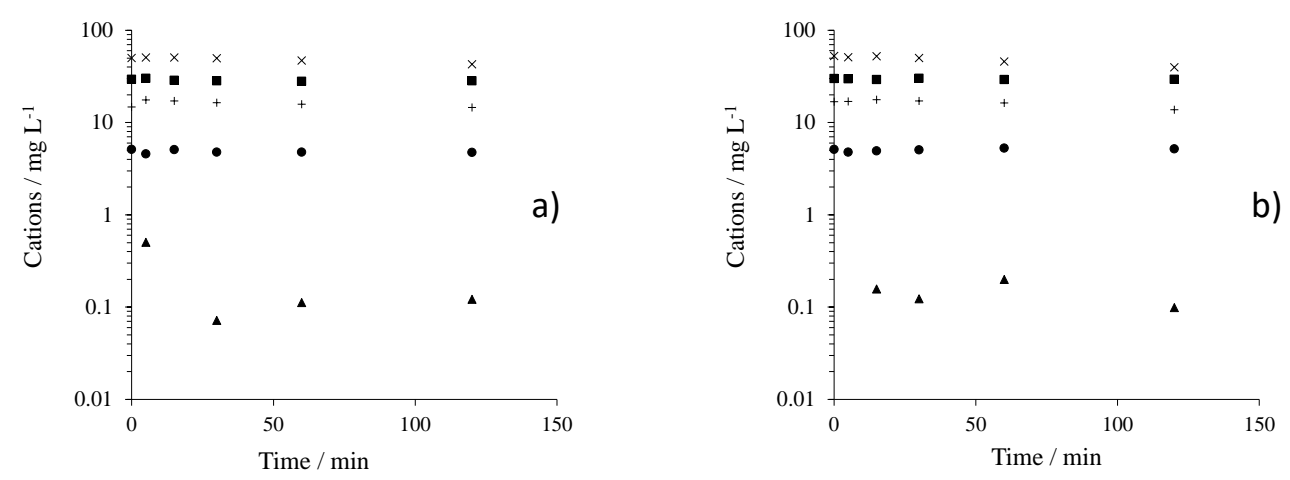

Figure 9. Changes in the concentration of anions during the electrolysis carried out in discontinuous mode at a) $83.3 \mathrm{~A} \mathrm{~m}^{-2}$ and b) $833.3 \mathrm{~A} \mathrm{~m}^{-2}$. Cations: $\mathbf{N} \mathrm{Na}^{+} ; \boldsymbol{\Delta} \mathrm{NH}_{4}{ }^{+}$; $\mathrm{K}^{+} ; \mathrm{x} \mathrm{Ca}{ }^{2+} ;+\mathrm{Mg}^{2+}$

\section{Conclusions}

From this work, the following conclusions can be drawn:

- Electrolysis with CabECO ${ }^{\circledR}$ cell is able to eliminate the microbial contamination of a surface water with fecal pollution. The disinfection rate and the amount of microorganism that remain in the solutions after the treatment depend on the current density and charge per liter supplied. Electrochemical technology exhibits better performance in disinfection than in sterilization.

- Under the experimental conditions required for an efficient disinfection, the degradation of organic substances is not very high (50\% in 2 hours of electrolysis) 
and hence the combined disinfection/removal of persistent organic pollutants is not a feasible application of this technology.

- The cocktail of oxidants formed during the electrolysis, including ozone (which was the key oxidant in the design of the cell) and persistent disinfectants such as hypochlorite and chloramines are the main responsible of the disinfection action of the process.

- During electrolysis, the formation of non-desirable chlorinated species can take place. Formation of chlorate and perchlorate is not favored at low current densities. The low concentration of chlorides in the water disinfected minimize this problem. In all cases, THM concentration were low and much below the limits set by the Spanish regulation (100 ppb).

\section{Acknowledgments}

This research belongs to the SafeWaterAfrica project, funded by the European Union's Horizon 2020 research and innovation programme under grant agreement No 689925.

\section{References}

APHA-AWWA-WPCF, 1998. Standard Methods for the Examination of Water and Wastewater, 20th edition ed, Washington, DC.

Arapoglou, D., Vlyssides, A., Israilides, C., Zorpas, A., Karlis, P., 2003. Detoxification of methyl-parathion pesticide in aqueous solutions by electrochemical oxidation. Journal of Hazardous Materials 98, 191-199.

Bergmann, M.E.H., Rollin, J., lourtchouk, T., 2009. The occurrence of perchlorate during drinking water electrolysis using BDD anodes. Electrochimica Acta 54, 2102-2107. Canizares, P., Saez, C., Sanchez-Carretero, A., Rodrigo, M.A., 2009. Synthesis of novel oxidants by electrochemical technology. Journal of Applied Electrochemistry 39, 21432149.

Cano, A., Barrera, C., Cotillas, S., Llanos, J., Canizares, P., Rodrigo, M.A., 2016. Use of DiaCell modules for the electro-disinfection of secondary-treated wastewater with diamond anodes. Chemical Engineering Journal 306, 433-440.

Cano, A., Canizares, P., Barrera, C., Saez, C., Rodrigo, M.A., 2011. Use of low current densities in electrolyses with conductive-diamond electrochemical - Oxidation to disinfect treated wastewaters for reuse. Electrochemistry Communications 13, 1268-1270. 
Cano, A., Canizares, P., Barrera-Diaz, C., Saez, C., Rodrigo, M.A., 2012. Use of conductive-diamond electrochemical-oxidation for the disinfection of several actual treated wastewaters. Chemical Engineering Journal 211, 463-469.

Cotillas, S., de Vidales, M.J.M., Llanos, J., Saez, C., Canizares, P., Rodrigo, M.A., 2016. Electrolytic and electro-irradiated processes with diamond anodes for the oxidation of persistent pollutants and disinfection of urban treated wastewater. Journal of hazardous materials 319, 93-101.

Freytag, H., 1959. Zur Bestimmung von Hypochlorit, Chlorid und Chlorat in Chlorkalk. Z. Anal. Chem. 171, 458-458.

Fryda, M., Behrendt-Fryda, B., Hampel, A., Heesch, L., Matthee, T., Fischer, M., Schmidt, W., 2016. ELECTROCHEMICAL DISINFECTION WITH BORON DOPED DIAMOND ELECTRODES AND REDUCTION OF ELECTROLYSIS BY-PRODUCTS. Disinfection by-Products in Drinking Water, 128-135.

Fryda, M., Matthee, T., Disinfecting system for low conductivity liquids, especially water, comprises electrochemical cell with electrodes for generating oxidants, with unit for thoroughly mixing the oxidants and liquid. Condias Gmbh; Fryda M; Matthee T.

Heim, C., de Vivanco, M.U., Rajab, M., Mueller, E., Letzel, T., Helmreich, B., 2015. Rapid inactivation of waterborne bacteria using boron-doped diamond electrodes. International Journal of Environmental Science and Technology 12, 3061-3070.

Kolosov, A.Y., Popov, K.I., Shabanova, N.A., Artem'eva, A.A., Kogut, B.M., Frid, A.S., Zel'venskii, V.Y., Urinovich, E.M., 2001. Electrokinetic removal of hydrophobic organic compounds from soil. Russian Journal of Applied Chemistry 74, 631-635.

Labiadh, L., Barbucci, A., Carpanese, M.P., Gadri, A., Ammar, S., Panizza, M., 2016. Comparative depollution of Methyl Orange aqueous solutions by electrochemical incineration using TiRuSnO2, BDD and $\mathrm{PbO} 2$ as high oxidation power anodes. Journal of Electroanalytical Chemistry 766, 94-99.

Lacasa, E., Canizares, P., Llanos, J., Rodrigo, M.A., 2011. Removal of nitrates by electrolysis in non-chloride media: Effect of the anode material. Separation and Purification Technology 80, 592-599.

Louhichi, B., Ahmadi, M.F., Bensalah, N., Gadri, A., Rodrigo, M.A., 2008. Electrochemical degradation of an anionic surfactant on boron-doped diamond anodes. Journal of Hazardous Materials 158, 430-437.

Ma, J.W., Wang, F.Y., Huang, Z.H., Wang, H., 2010. Simultaneous removal of 2,4dichlorophenol and $\mathrm{Cd}$ from soils by electrokinetic remediation combined with activated bamboo charcoal. Journal of Hazardous Materials 176, 715-720.

Martin de Vidales, M.J., Millan, M., Saez, C., Canizares, P., Rodrigo, M.A., 2016. What happens to inorganic nitrogen species during conductive diamond electrochemical oxidation of real wastewater? Electrochemistry Communications 67, 65-68.

Oturan, M.A., Oturan, N., Lahitte, C., Trevin, S., 2001. Production of hydroxyl radicals by electrochemically assisted Fenton's reagent - Application to the mineralization of an organic micropollutant, pentachlorophenol. Journal of Electroanalytical Chemistry 507, 96-102.

Piuleac, C.-G., Saez, C., Canizares, P., Curteanu, S., Andres Rodrigo, M., 2012. Hybrid Model of a Wastewater-Treatment Electrolytic Process. International Journal of Electrochemical Science 7, 6289-6301.

Pulgarin, C., Kiwi, J., 1996. Overview on photocatalytic and electrocatalytic pretreatment of industrial non-biodegradable pollutants and pesticides. Chimia 50, 50-55.

Rajab, M., Heim, C., Letzel, T., Drewes, J.E., Helmreich, B., 2015. Electrochemical disinfection using boron-doped diamond electrode - The synergetic effects of in situ ozone and free chlorine generation. Chemosphere 121, 47-53.

Ribeiro, A.B., Rodriguez-Maroto, J.M., Mateus, E.P., Gomes, H., 2005. Removal of organic contaminants from soils by an electrokinetic process: the case of atrazine. Experimental and modeling. Chemosphere 59, 1229-1239.

Rodrigo, M.A., Canizares, P., Buitron, C., Saez, C., 2010. Electrochemical technologies for the regeneration of urban wastewaters. Electrochimica Acta 55, 8160-8164. 
Sanchez-Carretero, A., Saez, C., Canizares, P., Rodrigo, M.A., 2011. Electrochemical production of perchlorates using conductive diamond electrolyses. Chemical Engineering Journal 166, 710-714.

Schaefer, C.E., Andaya, C., Urtiaga, A., 2015. Assessment of disinfection and by-product formation during electrochemical treatment of surface water using a Ti/lrO2 anode. Chemical Engineering Journal 264, 411-416.

Skoumal, M., Arias, C., Lluis Cabot, P., Centellas, F., Antonio Garrido, J., Maria Rodriguez, R., Brillas, E., 2008. Mineralization of the blocide chloroxylenol by electrochemical advanced oxidation processes. Chemosphere 71, 1718-1729.

Valero, P., Verbel, M., Silva-Agredo, J., Mosteo, R., Ormad, M.P., Torres-Palma, R.A., 2017. Electrochemical advanced oxidation processes for Staphylococcus aureus disinfection in municipal WWTP effluents. Journal of Environmental Management 198, 256-265.

Velazquez-Pena, S., Saez, C., Canizares, P., Linares-Hernandez, I., Martinez-Miranda, V., Barrera-Diaz, C., Rodrigo, M.A., 2013. Production of oxidants via electrolysis of carbonate solutions with conductive-diamond anodes. Chemical Engineering Journal 230, 272-278.

Vlyssides, A., Arapoglou, D., Mai, S., Barampouti, E.M., 2004. Electrochemical detoxification of two phosphorodithioate obsolete pesticides stocks. Fresenius Environmental Bulletin 13, 760-768.

Wilpert, A.v., 1957. Über die Analyse von Hypochlorit und Chlorit in einer Lösung. Z. Anal. Chem. 155, 378-378.

Yuan, S., Tian, M., Lu, X., 2006. Electrokinetic movement of hexachlorobenzene in clayed soils enhanced by Tween 80 and beta-cyclodextrin. Journal of Hazardous Materials 137, 1218-1225. 